\title{
Pengaruh Keragaman Penggunaan Lahan di Ekosistem Gambut sub DAS Kapuas Kabupaten Kubu Raya
}

\author{
Rima Wahyu Utari ${ }^{1}$, Kartini $^{2}$, Aji Ali Akbar ${ }^{1, *}$ \\ 1Jurusan Teknik Lingkungan, Fakultas Teknik Universitas Tanjungpura \\ 2Jurusan Teknik Sipil, Fakultas Teknik Universitas Tanjungpura
}

\begin{abstract}
Abstrak
Lahan gambut merupakan komponen ketahanan lingkungan yang diupayakan untuk menjamin keamanan publik dan munculnya bahaya lingkungan yang disebabkan secara alami oleh alam maupun disengaja oleh perbuatan manusia. Lahan gambut di Desa Teluk Empening telah mengalami konversi menjadi lahan usahatani seperti lahan sawit, karet dan jahe, sedangkan lahan sekunder yang ada pada daerah penelitian sebelumnya pernah mengalami kebakaran pada tahun 2017. Penelitian ini dilakukan dengan mengidentifikasi keanekaragaman jenis pada lahan gambut dengan melakukan pengukuran biodiversitas lahan dengan analisis vegetasi. Kemudian menganalisis pengaruh konversi lahan gambut dengan pengukuran sifat fisik tanah, pengukuran Tinggi Muka Air tanah, pengukuran dimensi saluran dan pengujian kualitas air. Perubahan dinamika tutupan lahan yang dipengaruhi oleh kondisi sosial ekonomi masyarakat, data diperoleh dengan menggunakan observasi, wawancara dan kuesioner sebanyak 30 sampel. Hasil analisis menunjukkan lahan jahe, karet dan sawit memiliki nilai indeks keanekaragaman $\left(\mathrm{H}^{\prime}\right) \pm 0$ dikategorikan biodiversitas rendah. Lahan sekunder memiliki nilai indeks keanekaragaman (H') 2,001 masuk kategori biodiversitas sedang. Konversi lahan gambut mempengaruhi sifat fisik tanah gambut seperti parameter porositas, permeabilitas, kadar serat dan kadar air. Konversi lahan gambut menjadi lahan karet memengaruhi penurunan muka air tanah yaitu setinggi $68 \mathrm{~cm}$. Pengaruh konversi terhadap kualitas air pada lahan, ditandai dengan parameter pH berkisar 3,3 - 4,6, TSS berkisar 6-440 mg/l dan DO berkisar 0,89-3,4 mg/l yang tidak sesuai dengan baku mutu yang ditetapkan yaitu Kelas 2 PP No.82 Tahun 2001. Konversi lahan gambut semakin meningkat tiap tahun dan mempengaruhi kondisi sosial ekonomi masyarakat dengan fungsi sosial penyerapan tenaga kerja serta fungsi ekonomi pendapatan dari hasil produksi usahatani. Lahan gambut memberikan keunggulan dan kapasitas bagi kawasan lokal untuk kekuatan alam seperti lingkungan, ekonomi dan sosial yang dapat dilakukan sambil tetap menjaga daya tahan lingkungan.
\end{abstract}

Kata kunci: Lahan Gambut, Konversi, Ketahanan Lingkungan, Sosial Ekonomi

\begin{abstract}
Peatlands are a component of environmental resilience that strives to ensure the safety and security of environmental hazards caused naturally or intentionally by human actions. Peatland in Teluk Empening Village has undergone conversion to agricultural land such as oil palm, rubber and ginger, while the secondary land in the previous study area experienced fires in 2017. This research was conducted by identifying the diversity of species on peatland by measuring biodiversity land with vegetation analysis. Then analyze the effect of peat land conversion with physical measurements of soil, measurement of groundwater level, measurement of channel dimensions and testing of water quality. Changes in land cover dynamics obtained from socio-economic conditions, data obtained using observations, interviews and questionnaires as many as 30 samples. The analysis showed that ginger, rubber and oil palm land had a diversity index value $\left(\mathrm{H}^{\prime}\right) \pm 0$ which was categorized as low biodiversity. Secondary land has a diversity index value $\left(\mathrm{H}^{\prime}\right)$ of 2,001 in the medium biodiversity category. Peat land conversion affects the physical properties of peat soil such as parameters of porosity, permeability, fiber content and air content. The conversion of peatlands to rubber lands has an effect on the decrease in the water table, which is $68 \mathrm{~cm}$ long. The effect of conversion on water quality in land, fear with pH parameters ranging from 3.3 to 4.6, TSS ranging from 6-440 mg / l and DO ranging from 0.89-3.4 mg / l which are not in accordance with the specified quality standards namely Class 2 PP No. 82 Year 2001. Conversion of peatlands is increasing every year and affects the socio-economic conditions of the community with the social function of absorption of labor and the economic function of income from agricultural production. Peatlands provide advantages and capacities for local areas for natural forces such as environment, economy and social that can be done while maintaining environmental resilience.
\end{abstract}

Keywords: Peatlands, Conversion, Environmental Resilience, Socio-Economy

Citation: Utari, R. W., Kartini, dan Akbar, A. A. (2021). Pengaruh Keragaman Penggunaan Lahan di Ekosistem Gambut sub DAS Kapuas Kabupaten Kubu Raya. Jurnal Ilmu Lingkungan, 19(2), 409-421, doi:10.14710/jil.19.2.409-421

*Penulis Korespondensi: aji.ali.akbar.2011@gmail.com 


\section{Pendahuluan}

Ketahanan lingkungan adalah satu diantara bagian dari ketahanan nasional, yang diupayakan untuk menjamin kesejahteraan publik dan perkembangan bahaya alam yang terjadi secara alami atau sengaja disebabkan oleh aktivitas manusia. Lahan gambut merupakan satu diantara segmen kekuatan alam yang memberikan keunggulan dan kapasitas bagi kawasan lokal akan kelenturan ekologi seperti lingkungan, ekonomi dan sosial (Irma dkk, 2018).

Konversi lahan gambut membuat lahan gambut tidak dapat berfungsi sesuai dengan peruntukannya (Veloo dkk, 2015; Ritzema dkk, 2014). Keanekaragaman hayati yang ada di lahan gambut sangat bervariasi salah satunya adalah biodiversitas vegetasi (Yuningsih dkk,2018). Konversi lahan gambut menjadi perkebunan dan pertanian telah menyebabkan penurunan tingkat keanekaragaman hayati vegetasi yang tinggi (Yule, 2010; Turetsky dkk, 2015), yang menjadi perhatian serius bagi upaya pelestarian dan perlindungan ekosistem. (Barchia, 2012). Berbagai tentang pengalihan lahan telah dirumuskan dalam peraturan perundang-undangan, namun pelaksanaannya masih belum sesuai dengan ketentuan yang berlaku. (Pranoto dkk, 2016).

Lahan gambut di Desa Teluk Empening, Kecamatan Terentang, Kabupaten Kubu Raya, Kalimantan Barat telah mengalami konversi lahan gambut menjadi perkebunan dan pertanian. Sehingga diperlukan kebijakan perlindungan ekosistem gambut terhadap konversi lahan gambut dengan mengetahui ketahanan lingkungan diatasnya sehingga tidak terjadi penurunan kualitas lingkungan. Tujuan penelitian ini adalah untuk mengetahui kondisi keanekaragaman jenis vegetasi pada lahan gambut, pengaruh konversi lahan gambut terhadap ketahanan lingkungan, dan dinamika perubahan konversi lahan gambut.

\section{Metode Penelitian}

\subsection{Lokasi dan Waktu penelitian}

Penelitian ini dilaksanakan di desa Teluk Empening Kecamatan Terentang, Kabupaten Kubu Raya. Pemilihan lokasi dilakukan berdasarkan tujuan penelitian dan pertimbangan/kriteria tertentu (purposive sampling). Dalam purposive sampling, pemilihan sampel didasarkan pada penelitian pribadi peneliti, menunjukkan bahwa sampel yang dipilih memang representatif. Kriteria desa yang dipilih adalah desa yang sebagian masyarakatnya telah memanfaatkan lahan gambut menjadi lahan usahatani sebagai sumber pendapatan dalam memenuhi kebutuhan hidupnya. Penelitian dilaksanakan pada bulan Juli 2020. Peta lokasi penelitian diperlihatkan pada Gambar 1 .

\subsection{Alat dan Bahan}

Peralatan yang digunakan saat penelitian di lapangan diantaranya GPS (Global Positioning System) Garmin S64, meteran $50 \mathrm{~m}$, meteran $2 \mathrm{~m}$, meteran $5 \mathrm{~m}$, tongkat, tali rapia, ember, sampling bailer, $\mathrm{pH}$ meter, thermometer, DO meter, botol sampel, bor tanah, pipa PVC $2 \mathrm{~m}$, waring, kawat,dop, tabung tanah, ring tanah $1,6 \mathrm{~cm}$ dan $6,5 \mathrm{~cm}$, pycnometer, gelas ukur, wadah, kompor, spatula, timbangan analitik, ayakan 20 mesh, palu, kertas, kontainer, suntikan, oven, desikator, kertas saring, cawan gooch, kaca arloji, gelas ukur, pipet volumetrik, pinset, kantong plastik, tisu, lakban, gunting, label, spidol dan alat tulis.
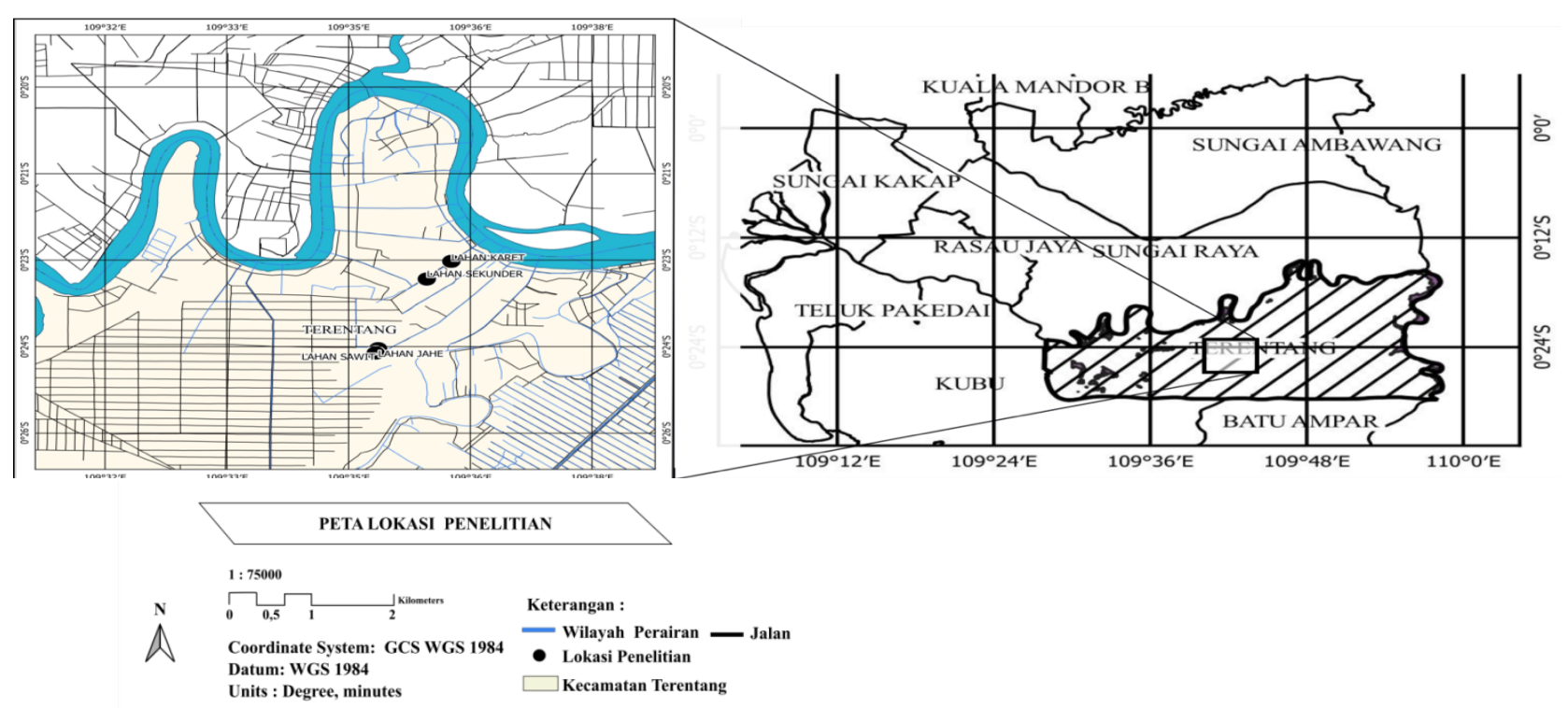

Sumber: Agraria Kab. Kubu Raya, 2019

Badan Informasi Geospasial

Gambar 1 Peta Lokasi Penelitian 
Bahan - bahan yang digunakan dalam penelitian diantaranya adalah akuades, sampel air muka tanah dan sampel air dari saluran lahan. Pembuatan peta pemodelan menggunakan aplikasi Google Earth dan ArcGis dengan bahan peta administrasi Kabupaten Kubu Raya dan peta dasar tata guna lahan Kecamatan Terentang Kabupaten Kubu Raya.

\subsection{Langkah Kerja}

\section{i) Identifikasi Keanekaragaman Jenis}

Identifikasi keanekaragaman jenis dilakukan dengan pengukuran biodiversitas lahan menggunakan metode survei untuk menentukan lokasi titik pengambilan sampel kemudian analisis vegetasi tutupan lahan dilakukan dengan Metode Releve yaitu melakukan segmentasi vegetasi, sehingga dapat ditentukan batas-batas komunitas dari suatu vegetasi. untuk lahan jahe dibuat luas petak ukur $25 \mathrm{~m}^{2}$. Sedangkan untuk hutan sekunder, lahan karet dan lahan sawit menggunakan luas petak ukur $400 \mathrm{~m}^{2}$.

\section{ii) Analisis Pengaruh Konversi Gambut}

Analisis Pengaruh Konversi Gambut dilakukan dengan beberapa langkah yaitu (1) Pengukuran Sifat Fisik Gambut dengan mengambil Sampel tanah dari satu titik di setiap petak pengamatan, dengan kedalaman 0-30 cm dan 30-60 cm. Sampel diambil dengan menggunakan sekop mini dan disimpan dalam ring sampel, lalu ditutup dengan tutup ring. untuk analisis parameter sifat fisik tanah. (2) Pengukuran tinggi muka air tanah dengan titik sampel muka air tanah sebanyak 9 pipa . Frekuensi pengukuran tinggi muka air tanah sebanyak 3 hari sekali selama 1 bulan dengan waktu pengukuran tinggi muka air tanah dilakukan pada jam 7 pagi dan jam 4 sore. (3) Pengukuran kualitas air, sebanyak 3 sampel air didalam pipa dan air sampel air di saluran diambil menggunakan sampling bailer untuk kemudian diukur kualitas airmya .Sampel air akan diuji dengan beberapa parameter diantaranya suhu, pH, DO dan TSS. (4) Pengukuran Dimensi Saluran, di lahan penelitian dilakukan secara langsung dengan mengukur dimensi saluran berupa panjang, lebar serta ketinggian muka air saluran guna mengetahui pengaruh keberadaan saluran terhadap biodiversitas vegetasi yang ada pada lahan penelitian.

\section{iii) Mengkaji Perubahan Tutupan Lahan}

Mengkaji Perubahan Tutupan Lahan dilakukan dengan Pembuatan Peta Dinamika Konversi Lahan Gambut dengan software Google Earth dan ArcGis, peta yang dibuat adalah perbandingan tutupan lahan akibat konversi lahan 10 tahun lampau dan eksistingnya sekarang. Serta melakukan Pengumpulan Data Sosial dan Ekonomi dengan menentukan sampel populasi dengan karakteristik tertentu yang memenuhi jumlah kuorum kelompok, dalam penelitian ini kuota sampel sebanyak 30 sampel.

\subsection{Analisis Data}

\section{i) Analisis Vegetasi}

Analisis vegetasi keanekaragaman hayati menggunakan indeks nilai penting jenis tumbuhan yang ditemukan pada tempat naungan dan tanpa naungan dihitung dengan menggunakan rumus:

$\mathrm{INP}=\mathrm{KR}+\mathrm{FR}+\mathrm{DR}$

a) Densitas (K) (ind/ha) = Jumlah Individu Suatu Jenis Luas Plot

b) Densitas Relatif (K) (ind/ha) = Kerapatan Suatu Jenis x 100\% Kerapatan Seluruh Jenis

c) Frekuensi (F) = Jumlah jenis (i) yang ditemukan di lokasi studi Jumlah Seluruh jenis yang ditemukanPlot

d) Frekuensi Relatif (FR) (\%) = Frekuensi Suatu Jenis $\mathrm{x} 100 \%$ Frekuensi Seluruh Jenis

e) Dominansi (D) (m2/ha) = Luas bidang dasar suatu jenis Luas Plot

f) Dominansi Relatif (DR) (\%) = Dominansi Suatu Jenis $x 100 \%$ Dominansi Seluruh Jenis

g) Indeks Nilai Penting (INP) $=\mathrm{KR}+\mathrm{FR}+\mathrm{DR}$..

h) Indeks Keanekaragaman Shannon-Wiener

$\left(\mathrm{H}^{\prime}\right)=-\sum\{(\mathrm{n} . \mathrm{i} / \mathrm{N}) \ln (\mathrm{n} . \mathrm{i} / \mathrm{N})\}$

Dengan :

$\mathrm{H}=$ Indeks keanekaragamn Shannon-Wiener

$\mathrm{N}=$ Total nilai penting

n.i = Nilai penting dari tiap spesies

Nilai Indeks Biodiversitas vegetasi yang ada di lahan gambut sub DAS Kapuas Terentang pada masing masing sampel yang dihitung menggunakan rumus Shannon Wienner, yaitu jika $\mathrm{H}^{\prime}>3$ jenis keanekaragaman hayati tinggi, sebaran jumlah individu pada setiap spesies lebih tinggi, dan stabilitas komunitas juga lebih tinggi. Jika H'1-3 kelas keanekaragaman hayati sedang, sebaran jumlah individu pada tiap spesies sedang, kestabilan komunitas sedang, dan kategori keanekaragaman hayati rendah $\mathrm{H}^{\prime}<1$, sebaran jumlah individu di setiap spesies rendah, dan stabilitas komunitas rendah. 
Tabel 1 Hasil Analisis Sifat Fisik Tanah Gambut

\begin{tabular}{|c|c|c|c|c|c|}
\hline & $\begin{array}{l}\text { Bobot isi } \\
\left(\mathrm{gr} / \mathrm{cm}^{3}\right)\end{array}$ & $\begin{array}{c}\text { Berat } \\
\text { Jenis } \\
\text { Partikel } \\
\left(\mathrm{gr} / \mathrm{cm}^{3} \text { ) }\right.\end{array}$ & $\begin{array}{l}\text { Porositas } \\
\text { Total (\%) }\end{array}$ & $\begin{array}{c}\text { Kadar Air } \\
\text { Kondisi } \\
\text { Lapangan } \\
\text { (\%Grav) }\end{array}$ & $\begin{array}{c}\text { Permeabilitas } \\
\text { (cm/detik) }\end{array}$ \\
\hline Sawit A 30 & 1,029 & 1,447 & 87,662 & 494,915 & $6,114 \mathrm{E}-06$ \\
\hline Sawit B 30 & 1,031 & 1,391 & 85,841 & 458,489 & $2,091 \mathrm{E}-06$ \\
\hline Sawit C 30 & 1,114 & 1,736 & 91,883 & 688,367 & $7,340 \mathrm{E}-06$ \\
\hline Sawit A 60 & 1,052 & 1,346 & 84,046 & 405,623 & $6,114 \mathrm{E}-06$ \\
\hline Sawit B 60 & 1,042 & 1,452 & 86,515 & 466,211 & $3,229 \mathrm{E}-06$ \\
\hline Sawit C 60 & 1,068 & 1,336 & 83,760 & 430,389 & $8,006 \mathrm{E}-06$ \\
\hline Jahe A 30 & 1,127 & 1,162 & 81,991 & 434,094 & $2,296 \mathrm{E}-06$ \\
\hline Jahe B 30 & 1,221 & 1,684 & 83,898 & 313,559 & $5,456 \mathrm{E}-06$ \\
\hline Jahe C 30 & 1,047 & 1,290 & 84,125 & 428,630 & $2,674 \mathrm{E}-06$ \\
\hline Jahe A 60 & 1,088 & 1,330 & 83,208 & 391,748 & $3,923 \mathrm{E}-06$ \\
\hline Jahe B 60 & 1,100 & 1,100 & 79,138 & 417,367 & $8,962 \mathrm{E}-06$ \\
\hline Jahe C 60 & 1,203 & 1,866 & 83,450 & 281,742 & $4,084 \mathrm{E}-06$ \\
\hline Karet A 30 & 1,056 & 1,272 & 81,430 & 363,075 & $6,113 \mathrm{E}-06$ \\
\hline Karet B 30 & 1,033 & 1,023 & 80,424 & 440,680 & $1,499 \mathrm{E}-06$ \\
\hline Karet C 30 & 1,041 & 1,023 & 70,685 & 270,159 & $2,504 \mathrm{E}-06$ \\
\hline Karet A 60 & 1,029 & 1,100 & 82,429 & 465,872 & $1,116 \mathrm{E}-05$ \\
\hline Karet B 60 & 1,019 & 1,070 & 84,851 & 574,475 & $2,646 \mathrm{E}-06$ \\
\hline Karet C 60 & 1,073 & 1,275 & 83,127 & 413,002 & $2,674 \mathrm{E}-06$ \\
\hline Sekunder A 30 & 1,060 & 1,263 & 87,441 & 587,164 & $2,296 \mathrm{E}-06$ \\
\hline Sekunder B 30 & 1,044 & 1,464 & 94,246 & 1196,369 & $1,120 \mathrm{E}-06$ \\
\hline Sekunder C 30 & 1,043 & 1,173 & 84,737 & 519,602 & $2,789 \mathrm{E}-06$ \\
\hline Sekunder A 60 & 1,047 & 1,405 & 94,115 & 1191,566 & $6,710 \mathrm{E}-06$ \\
\hline Sekunder B 60 & 1,031 & 1,363 & 91,815 & 857,004 & $7,450 \mathrm{E}-06$ \\
\hline Sekunder C 60 & 1,025 & 1,173 & 92,653 & 1183,320 & $6,114 \mathrm{E}-06$ \\
\hline
\end{tabular}

Sumber : Hasil Analisis, 2020

\section{Hasil dan Pembahasan}

\subsection{Pengaruh Konversi Lahan Gambut}

Penggunaan lahan gambut tropis yang bijak telah ditekankan menjadi pertimbangan antara pembangunan dan konservasi. Sementara budidaya tanaman tahunan seperti kelapa sawit dan karet pada lahan gambut dapat dilihat sebagai solusi untuk pembangunan pedesaan, konversi lahan gambut juga dapat menyebabkan degradasi dan fragmentasi lahan gambut akibat aktivitas manusia (Veloo, dkk, 2015 ; Ritzema, dkk, 2014).

\subsection{Sifat Fisik Tanah Gambut}

Sifat fisik tanah gambut pada Tabel $\mathbf{1}$ merupakan komponen morfologi penting yang memberikan fasilitas pertumbuhan tanaman dan mempengaruhi kesuburan tanah, yang pada akhirnya akan mendukung pertumbuhan tanaman, bahkan lebih penting dari pada sifat kimia dan biologi tanah. (Suswati,dkk, 2011; Wasis dkk, 2005). Sifat fisik tanah yang baik juga akan memberikan kualitas lingkungan yang baik pula, oleh karena itu sifat fisik tanah dijadikan sebagai pertimbangan dalam menetapkan suatu lahan untuk pertanian (Yulnafatmawita dkk, 2007).

\section{i) Ketebalan dan Kematangan Gambut}

Berdasarkan hasil penelitian tingkat kematangan gambut pada Desa Teluk Empening termasuk kategori gambut hemik dan teridentifkasi masuk ke dalam kategori sedang dan dalam. Kedalaman lahan gambut teridentifikasi berkisar antara $140 \mathrm{~cm}$ hingga $260 \mathrm{~cm}$. Gambut yang matang cenderung lebih halus dan lebih subur, sedangkan di sisi lain gambut yang belum menghasilkan lebih banyak serat dan kurang subur. (Najiyati dkk, 2005). Pemanfaatan lahan gambut sebagai suatu potensi budidaya tanamanan pangan harus memperhatikan ketebalan gambut. Hal ini dikarenakan semakin tebal tanah gambut, maka semakin rendah pula potensinya untuk budidaya 
tanaman pangan dan hortikultura (Masganti, Anwar, \& Susanti, 2017).

\section{ii) Bobot Isi}

Lokasi penelitian yang terletak di jalur aliran sungai, gambut pantai dan gambut yang terletak di jalur aliran sungai memiliki bobot isi yang relatif lebih tinggi, yakni $>0,2 \mathrm{~g} \mathrm{~cm}-3$ karena adanya pengaruh bahan mineral (Perdana \& Wawan, 2015). Tingkat kematangan gambut berpengaruh terhadap besarnya bobot isi, semakin matang gambut, rata-rata bobot isi gambut menjadi lebih tinggi (Dariah, Maftuah, \& Maswar, 2014). Peningkatan kepadatan berdampak pada peningkatan nilai bobot isi tanah gambut hingga kedalaman tertentu. Tekanan atau pemadatan menyebabkan butiran dan serat-serat gambut bergerak dan mengisi pori-pori makro, sehingga tanah gambut menjadi lebih padat Pengaruh tekanan beban dari atas menyebabkan adanya proses pemampatan bahan penyusun tanah gambut dan terjadi pengurangan rongga-rongga udara, hal ini dapat menyebabkan peningkatan nilai bobot isi tanah gambut (Perdana \& Wawan, 2015).

\section{iii) Berat Jenis Partikel}

Berdasarkan hasil analisis berat jenis partikel tanah gambut pada lahan sawit diketahui nilai berat jenis partikel berkisar antara 1,34-1,74 gr/cm3, berat jenis partikel tanah gambut pada lahan jahe berkisar antara 1,1-1,97 $\mathrm{gr} / \mathrm{cm} 3$, berat jenis partikel tanah gambut di lahan karet berkisar antara 1,02-1,61 $\mathrm{gr} / \mathrm{cm} 3$ berat jenis partikel terendah ditemukan pada lahan karet dengan nilai $1,02 \mathrm{gr} / \mathrm{cm} 3$ dan berat jenis partikel tanah gambut pada lahan sekunder berkisar antara 1,05-1,49 gr/cm3. Nilai densitas partikel 1,4 g / $\mathrm{cm} 3$ yang saat ini digunakan sebagai acuan tergolong rendah. Nilai berat jenis partikel gambut tropis dan subtropis yang bervariasi di atas 1,4 g / cm3 (Faoziah, Iskandar, Djajakirana, Darmawan, \& Sumawinata, 2019). Angka berat jenis partikel harus lebih tinggi dibandingkan nilai bobot isi, karena semua pori sudah dikeluarkan. . Nilai berat jenis partikel yang semakin besar terhadap nilai bobot isi, maka kandungan ruang pori di dalam tanah juga menjadi besar. Demikian juga sebaliknya jika angka berat jenis partikel tetap akan tetapi nilai bobot isi makin besar, maka dipastikan total pori tanah semakin sedikit (Munir \& Herman, 2019).

\section{iv) Porositas}

Hasil penelitian menunjukkan nilai porositas gambut pada lahan sawit berkisar antara 83,76\% hingga 91,88\%. Nilai porositas gambut pada lahan jahe berkisar antara 79,14\% hingga 84,13\% sedangkan nilai porositas gambut pada lahan karet yaitu 70,69\% hingga $84,85 \%$ dimana $70,69 \%$ merupakan hasil nilai porositas terendah diantara ke empat jenis lahan. Nilai porositas lahan sekunder yaitu berkisar $84,74 \%$ hingga
94,11\% dimana 94,11\% merupakan nilai porositas gambut tertinggi dari empat jenis lahan yang berbeda. Akibat konversi lahan menjadi lahan perkebunan sawit, jahe, dan karet berakibat pada meningkatnya kepadatan tanah yang tinggi dan tingkat porositas atau distribusi pori tanah akan semakin menurun (Surya, Nuraini , \& Widianto, 2017). Porositas dan distribusi ukuran pori mempengaruhi aliran dan penyimpanan air di gambut, karena porositas yang tinggi gambut dapat menyimpan air lebih tinggi (Sufardi, Basri, Ali, \& Khairullah, 2016). Keberadaan ruang pori tanah merupakan media untuk udara dalam menunjang pernafasan akar, aktivitas mikro organisme, dan penyerapan unsur hara (Rustam, Umar, \& Yusran, 2016).

\section{v) Permeabilitas}

Nilai permeabilitas yang didapat dari hasil penelitian ini lebih rendah dari nilai gambut tropis berdasarkan beberapa penelitian lain. Nilai gambut tropis menurut beberapa literatur berkisar antara 105 - 10-3 cm/detik (Melling, Katimon, Joo , Uyo, Sayok, \& Hatano, 2007), sedangkan rentang nilai gambut subtropis yakni 10-8 - 10-2 cm/detik (Gnatowski, Szatyłowicz, Brandyk, \& Kechavarzi, 2010). Gambut tropis didominasi oleh pohon-pohon yang merupakan spesies utama pembentuk gambut, sedangkan gambut subtropis didominasi oleh rumput dan semak-semak rendah. Akibatnya gambut tropis memiliki konduktivitas hidrolik lebih tinggi, terutama di lapisan atas karena memiliki pori yang lebih besar dari sisasisa pohon (Page, et al., 2009).

Beberapa faktor yang dapat mempengaruhi rendahnya nilai permeabilitas diantaranya jenis bahan gambut, tingkat dekomposisi, dan bobot isi (bulk density) (Andriesse, 1988). Nilai konduktivitas hidrolik dengan vegetasi berupa pohon-pohon lebih tinggi jika dibandingkan dengan nilai konduktivitas hidrolik pada vegetasi berupa semak-semak. Hal ini dikarenakan aktivitas akar pada pepohonan lebih tinggi dari aktivitas akar serabut pada semak-semak, sehingga permukaan dibawah pepohonan memiliki pori-pori yang lebih besar dan nilai konduktivitas hidrolik yang lebih tinggi (Prabandini, 2016). Konduktivitas hidrolik akan semakin kecil seiring dengan bertambahnya kedalaman. Hal ini dikarenakan tingkat kematangan gambut yang berbeda. Semakin dalam, tingkat dekomposisi gambut semakin tinggi. Hal ini menyebabkan porositas tanah berkurang, sehingga pori-pori yang terdapat dalam gambut akan semakin sedikit (Andriesse, 1988). Semakin besar nilai bobot isi (bulk density) maka nilai konduktivitas hidrolik akan semakin kecil dikarenakan sedikitnya rongga dalam tanah, yang akan menghambat pergerakan air (Lewis, Albertson, Xu, \& Kiely, 2011). Gambut pada lahan penelitian merupakan jenis gambut tropis, gambut tropis memiliki perbedaan karakteristik vegetasi dengan gambut subtropis. Hal ini menyebabkan nilai konduktivitas hidrolik yang dimiliki oleh gambut tropis 
berbeda dengan gambut subtropis. Gambut tropis memiliki nilai konduktivitas hidrolik yang lebih besar jika dibandingkan dengan gambut subtropis.

\section{vi) Kadar Serat}

Berdasarkan hasil analisis nilai kadar serat gambut pada 4 jenis lahan yang berbeda dapat dilihat bahwa rata - rata nilai kadar serat gambut berkisar antara 20 - 36\% yang berarti tingkat kematangan gambut pada 4 jenis lahan yang berbeda tersebut adalah hemik (setengah matang). Gambut hemik atau gambut setengah matang telah mengalami perubahan pemanfaatan dan fungsinya yang dapat menimbulkan sifat kering tak balik, cepat ambelas (subsiden), serta mudah melepaskan air apabila terjadi kerusakan (Wahdah, 2018 ). Tanah gambut dengan tingkat kematangan hemik memiliki kandungan bahan organik yang tinggi, hanya saja bahan alam tersebut belum terurai total sehingga tidak dapat memberikan sumber hara yang memadai bagi tanaman budidaya (Dariah, Maftuah, \& Maswar, 2014).

\section{vii) Kadar Air}

Hasil analisis nilai kadar air menunjukkan nilai yang bervariasi hal ini dapat disebabkan ketersediaan air tanah bukan hanya berdasarkan kematangannya saja, tetapi dipengaruhi juga oleh curah hujan atau air saluran drainase, kemampuan tanah menahan air, evapotranspirasi, dan tinggi muka air tanah (Saribun, 2007). Kadar air selain dipengaruhi oleh beberapa faktor tersebut juga dapat disebabkan oleh kepadatan tanah, karena tanah akan lebih sedikit memegang air (Mardiana, 2006).

Tabel 2 Hasil pengukuran Tinggi Muka Air

\begin{tabular}{|c|c|c|c|c|c|c|c|c|c|c|}
\hline \multirow[b]{2}{*}{ Jenis Lahan } & \multicolumn{5}{|c|}{ Sampel Pipa A } & \multicolumn{5}{|c|}{ Sampel Pipa B } \\
\hline & $1 \mathrm{~A}$ & $2 A$ & 3AB & $4 \mathrm{~A}$ & $\mathbf{5 A}$ & 1B & 2B & 3AB & 4B & 5B \\
\hline \multirow{10}{*}{ Sawit } & 35,5 & 28,5 & 24,5 & 23,5 & 30,5 & 38,5 & 21 & 24,5 & 30,5 & 30 \\
\hline & 35 & 26,5 & 26,5 & 21 & 31,5 & 35,5 & 26,5 & 26,5 & 29,5 & 31 \\
\hline & 35 & 21,5 & 27 & 20 & 28 & 35 & 28 & 27 & 28,5 & 31,5 \\
\hline & 35,5 & 19 & 25,5 & 18,5 & 28,5 & 34,5 & 30,5 & 25,5 & 28 & 30 \\
\hline & 35 & 28,5 & 28,5 & 30 & 30,5 & 37,5 & 32,5 & 28,5 & 30 & 29 \\
\hline & 36 & 26,5 & 28,5 & 30 & 30 & 37 & 32 & 28,5 & 29 & 28,5 \\
\hline & 32,5 & 26,5 & 28,5 & 29 & 30,5 & 36 & 31,5 & 28,5 & 28 & 29 \\
\hline & 34 & 26 & 28 & 28,5 & 30 & 34,5 & 31,5 & 28 & 28,5 & 28,5 \\
\hline & 33,5 & 26 & 27 & 29 & 29,5 & 35 & 31 & 27 & 28 & 28,5 \\
\hline & 34,5 & 26 & 26 & 29,5 & 29 & 34 & 30,5 & 26 & 27 & 29 \\
\hline \multirow{10}{*}{ Jahe } & 20 & 28 & 15,5 & 26 & 21 & 38,5 & 19 & 15,5 & 11,5 & 21,5 \\
\hline & 16 & 28,5 & 13,5 & 25 & 19 & 33 & 16 & 13,5 & 13,5 & 19,5 \\
\hline & 20 & 30 & 12,5 & 25 & 17,5 & 32 & 15,5 & 12,5 & 12,5 & 20 \\
\hline & 21,5 & 28 & 14 & 24,5 & 21 & 32 & 12 & 14 & 14 & 20 \\
\hline & 24 & 30 & 14,5 & 25 & 25,5 & 38,5 & 20 & 14,5 & 14 & 20 \\
\hline & 23 & 28 & 13 & 23 & 25 & 37 & 17,5 & 13 & 12 & 19 \\
\hline & 24 & 27,5 & 11,5 & 22 & 24 & 36,5 & 16,5 & 11,5 & 10,5 & 19 \\
\hline & 24,5 & 27 & 11,5 & 22 & 23 & 35,5 & 16 & 11,5 & 10,5 & 18 \\
\hline & 22,5 & 26,5 & 12 & 22 & 23,5 & 36,5 & 15,5 & 12 & 11 & 18,5 \\
\hline & 20 & 27 & 12 & 23 & 23 & 37 & 16,5 & 12 & 11 & 19 \\
\hline \multirow{10}{*}{ Karet } & 42 & 49 & 30,5 & 50 & 49,5 & 60,5 & 44,5 & 30,5 & 46,5 & 56 \\
\hline & 41,5 & 52 & 33 & 50,5 & 48,5 & 64 & 43,5 & 33 & 47,5 & 59 \\
\hline & 41 & 52,5 & 33,5 & 49,5 & 49 & 58,5 & 43,5 & 33,5 & 48,5 & 52 \\
\hline & 53 & 46,5 & 32 & 39,5 & 38,5 & 57,5 & 46,5 & 32 & 36 & 49 \\
\hline & 37 & 51 & 33,5 & 47,5 & 46 & 58 & 42 & 33,5 & 44,5 & 54,5 \\
\hline & 34 & 46,5 & 33 & 43,5 & 44 & 55 & 40 & 33 & 40,5 & 50 \\
\hline & 31,5 & 43 & 31,5 & 40 & 43 & 50,5 & 36 & 31,5 & 37,5 & 46 \\
\hline & 32 & 42,5 & 32 & 39,5 & 42,5 & 50 & 35,5 & 32 & 37 & 45,5 \\
\hline & 33 & 43,5 & 33,5 & 40,5 & 42,5 & 50 & 35,5 & 33,5 & 38 & 45 \\
\hline & 33 & 43 & 33,5 & 40 & 44 & 50,5 & 35 & 33,5 & 38,5 & 46 \\
\hline \multirow{10}{*}{ Sekunder } & 29 & 30,5 & 14,5 & 21 & 28 & 31,5 & 22,5 & 14,5 & 18 & 22,5 \\
\hline & 28,5 & 29 & 15,5 & 19,5 & 26,5 & 30,5 & 24,5 & 15,5 & 18,5 & 22 \\
\hline & 29,5 & 29,5 & 14 & 21 & 26 & 30 & 24,5 & 14 & 17,5 & 24,5 \\
\hline & 31,5 & 29 & 14,5 & 22 & 26,5 & 31 & 25,5 & 14,5 & 16 & 18,5 \\
\hline & 31 & 28 & 15,5 & 21,5 & 25,5 & 31 & 24,5 & 15,5 & 17,5 & 17 \\
\hline & 30,5 & 28,5 & 16,5 & 20,5 & 26 & 30,5 & 24 & 16,5 & 17,5 & 18 \\
\hline & 31 & 28,5 & 17 & 19,5 & 26,5 & 30 & 23 & 17 & 15,5 & 19,5 \\
\hline & 30 & 29,5 & 15,5 & 19 & 28 & 30,5 & 22,5 & 15,5 & 15,5 & 20,5 \\
\hline & 31,5 & 29 & 15 & 20,5 & 28,5 & 30,5 & 23 & 15 & 17,5 & 19,5 \\
\hline & 30,5 & 29 & 17 & 20 & 26,5 & 31 & 21,5 & 17 & 15 & 20,5 \\
\hline
\end{tabular}

Sumber : Hasil Analisis, 2020 


\subsubsection{Tinggi Muka Air Tanah dan Saluran}

Penelitian ini melihat pengaruh konversi lahan gambut menjadi empat jenis lahan yang berbeda yaitu perkebunan sawit, kebun jahe, kebun karet dan lahan sekunder terhadap tinggi muka air dan saluran. Hasil pengukuran Tinggi Muka Air dalam 10 hari didapatkan hasil seperti pada Tabel 2 Hasil pengukuran Tinggi Muka Air. Kedalaman muka air tanah memiliki peranan kunci dalam ekosistem gambut. Tinggi muka air tanah di 4 jenis lahan berbedabeda. Lahan sawit, lahan jahe dan lahan sekunder masih berada dibawah $40 \mathrm{~cm}$. Lahan yang memiliki tinggi muka air tanah paling rendah yaitu lahan karet karena melebihi $40 \mathrm{~cm}$. Menurunkan muka air tanah bermanfaat bagi spesies tumbuhan tertentu, tetapi dapat menyebabkan gambut mengering secara permanen dan meningkatkan laju pembusukan. Kisaran ketinggian air yang optimal adalah $60-100 \mathrm{~cm}$ untuk mencegah kekeringan dan kebakaran, 40-50 cm untuk mencegah ambiguitas, dan 30-40 cm untuk mendukung pertumbuhan tanaman sekunder (Noor dkk, 2013).

Menurut kondisi alam dan perakarannya, beberapa jenis tumbuhan memiliki persyaratan berbeda untuk kedalaman permukaan air. Perlu diupayakan agar kedalaman muka airtanah di darat tidak terlalu jauh dari akar tanaman, jika permukaan air terlalu dalam maka oksidasi yang berlebihan akan mempercepat rusaknya gambut dan mempercepat lunturnya gambut. (Yuliani, 2014). Hasil penelitian menunjukkan bahwa semakin dekat muka airtanah ke saluran drainase, maka muka airtanah semakin dalam.Menurut penelitian Azri (1999) dalam (Susandi dkk, 2015) hal ini disebabkan oleh peningkatan aliran yang terus menerus. Pergerakan air tanah, dan drainase menyebabkan berkurangnya air di dalam tanah gambut, pengurangan yang berujung pada berkurangnya jumlah air tanah, sehingga saluran drainase mempunyai pengaruh yang besar terhadap penurunan muka airtanah tanah gambut.

Prinsip utama pengelolaan air pada lahan gambut yang dikembangkan untuk tanaman pertanian adalah mampu membendung kerusakan alami lahan gambut akibat proses drainase/ penurunan muka air tanah, namun tetap dapat memenuhi kebutuhan tumbuh kembang tanaman. Selanjutnya, ketinggian air tanah harus diimbangi seminimal mungkin dimana tanaman masih bisa tumbuh, artinya ketinggian air tanah harus disesuaikan agar tidak terlalu dangkal atau terlalu dalam (Dariah \& Maswar, 2016).

Tabel 3 Hasil Analisis Parameter Kualitas Air

\begin{tabular}{clcccc}
\hline Jenis Lahan & \multicolumn{1}{c}{ Nama Sampel } & Ph & Suhu $\left.\mathbf{~}^{\circ} \mathbf{C}\right)$ & DO $\mathbf{~ ( m g / l )}$ & TSS \\
\hline \multirow{6}{*}{ Sekunder } & 4,6 & 31 & 1,9 & 440 \\
& Lahan Sekunder 1B & 4,1 & 29 & 2,15 & 193 \\
& Lahan Sekunder 3AB & 4 & 30 & 1,94 & 11 \\
& Lahan Sekunder 5B & 3,4 & 30 & 2,23 & 6 \\
& Lahan Sekunder Saluran Depan & 3,7 & 29 & 1,2 & 7 \\
& Lahan Sekunder Saluran Samping & 4,1 & 30 & 2,05 & 182 \\
& Lahan Karet 1B & 3,6 & 30 & 1,84 & 90 \\
& Lahan Karet 3AB & 3,7 & 29 & 2,3 & 45 \\
& Lahan Karet 5B & 3,9 & 32 & 2,43 & 110 \\
& Lahan Karet Saluran Depan & 3,7 & 30 & 0,89 & 21 \\
& Lahan Karet Saluran Samping & 3,3 & 29 & 3,4 & 152 \\
& Lahan Sawit 1B & 4,1 & 29 & 2,01 & 95 \\
& Lahan Sawit 3AB & 4 & 28 & 1,3 & 567 \\
& Lahan Sawit 5B & 4 & 30 & 3,1 & 142 \\
& Lahan Sawit Saluran Depan & 3,8 & 29 & 1,5 & 221 \\
& Lahan Sawit Saluran Samping & 4,5 & 29 & 1,9 & 77 \\
& Lahan Jahe 1B & 3,6 & 29 & 1,66 & 26 \\
& Lahan Jahe 3AB & 3,9 & 28 & 1,14 & 76 \\
& Lahan Jahe 5B & 3,9 & 30,05 & 3,1 & 145 \\
& Lahan Jahe Saluran Depan & 3,6 & 28 & 1,04 & 113 \\
\hline
\end{tabular}

Sumber : Hasil Analisis, 2020 


\subsubsection{Kualitas Air}

Konversi lahan gambut mempengaruhi kualitas air yang ada pada lahan, perubahan tutupan lahan dan masuknya zat-zat yang bertujuan untuk meningkatkan kesuburan lahan gambut dapat menurunkan kualitas air pada lahan ditandai dengan parameter pH berkisar antara 3,3 - 4,6, TSS berkisar antara 6-440 mg/l dan DO berkisar antara 0,89-3,4 $\mathrm{mg} / \mathrm{l}$ yang tidak sesuai dengan baku mutu yang ditetapkan yaitu Kelas 2 PP No.82 Tahun 2001

\subsection{Keanekaragaman Jenis Vegetasi Gambut}

Hasil analisis vegetasi disajikan pada tabel berikut:

Tabel 4. Analisis Vegetasi Tingkat Pohon dan Tingkat Pancang

\begin{tabular}{|c|c|c|c|c|c|c|c|c|c|}
\hline \multirow{2}{*}{ Tingkat } & \multicolumn{2}{|c|}{ Nama Jenis Vegetasi } & \multirow{2}{*}{ K } & \multirow{2}{*}{ KR } & \multirow{2}{*}{$\mathbf{F}$} & \multirow{2}{*}{ FR } & \multirow{2}{*}{ D } & \multirow{2}{*}{ DR } & \multirow{2}{*}{ INP } \\
\hline & Nama Lokal & Nama Ilmiah & & & & & & & \\
\hline \multirow{7}{*}{ Pohon } & Temasam & Syzgium cerina & 0,02 & 37,50 & 0,67 & 25,00 & 0,01 & 22,62 & 85,12 \\
\hline & Selai - selai & Sageraea Lanceolata & 0,01 & 25,00 & 0,67 & 25,00 & 0,00 & 8,37 & 58,37 \\
\hline & Tembesu & $\begin{array}{l}\text { Fagraea } \\
\text { cochinchinensis }\end{array}$ & 0,00 & 6,25 & 0,33 & 12,50 & 0,01 & 14,66 & 33,41 \\
\hline & Mahang & $\begin{array}{l}\text { Macaranga } \\
\text { motleyana }\end{array}$ & 0,01 & 12,50 & 0,33 & 12,50 & 0,00 & 1,85 & 26,85 \\
\hline & Mamali & Leea indica & 0,00 & 6,25 & 0,33 & 12,50 & 0,00 & 0,63 & 19,38 \\
\hline & Simpur Kijang & Dillenia eximia & 0,01 & 12,50 & 0,33 & 12,50 & 0,03 & 51,87 & 76,87 \\
\hline & \multicolumn{2}{|c|}{ Total } & 0,04 & 100 & 2,67 & 100 & 0,06 & 100 & 300 \\
\hline \multirow{8}{*}{ Pancang } & Temasam & Syzgium cerina & 0,12 & 7,50 & 0,33 & 9,09 & 0,01 & 3,51 & 20,11 \\
\hline & Selai - selai & Sageraea Lanceolata & 0,32 & 20,00 & 0,33 & 9,09 & 0,03 & 10,12 & 39,21 \\
\hline & Mahang & $\begin{array}{l}\text { Macaranga } \\
\text { motleyana }\end{array}$ & 0,60 & 37,50 & 1,00 & 27,27 & 0,02 & 5,45 & 70,22 \\
\hline & Mamali & Leea indica & 0,20 & 12,50 & 0,67 & 18,18 & 0,06 & 20,27 & 50,95 \\
\hline & Meranti & Shorea dasyphylla & 0,08 & 5,00 & 0,33 & 9,09 & 0,03 & 10,53 & 24,62 \\
\hline & Simpur Kijang & Dillenia eximia & 0,20 & 12,50 & 0,67 & 18,18 & 0,12 & 37,95 & 68,63 \\
\hline & Medang & $\begin{array}{l}\text { Teysmanniodendron } \\
\text { pteropodus }\end{array}$ & 0,08 & 5,00 & 0,33 & 9,09 & 0,04 & 12,17 & 26,26 \\
\hline & \multicolumn{2}{|c|}{ Total } & 1,60 & 100 & 3,67 & 100 & 0,32 & 100 & 300 \\
\hline
\end{tabular}

Sumber : Hasil Analisis, 2020

Tabel 5 Hasil Analisis Vegetasi Tingkat Semai

\begin{tabular}{|c|c|c|c|c|c|c|}
\hline \multicolumn{2}{|r|}{ Nama Jenis Vegetasi } & \multirow{2}{*}{$\mathbf{K}$} & \multirow{2}{*}{ KR } & \multirow{2}{*}{$\mathbf{F}$} & \multirow{2}{*}{ FR } & \multirow{2}{*}{ INP } \\
\hline Nama Lokal & Nama Ilmiah & & & & & \\
\hline Selai - selai & Sageraea Lanceolata & 1 & 2,63 & 0,33 & 7,69 & 10,32 \\
\hline Mahang & Macaranga motleyana & 4 & 10,53 & 0,67 & 15,38 & 25,91 \\
\hline Mamali & Leea indica & 2 & 5,26 & 0,67 & 15,38 & 20,65 \\
\hline Meranti & Shorea dasyphylla & 1 & 2,63 & 0,33 & 7,69 & 10,32 \\
\hline Cengkodok & Melastoma malabathricum & 26 & 68,42 & 1,00 & 23,08 & 91,50 \\
\hline Rambe Ayam & Aporosa arborea & 1 & 2,63 & 0,33 & 7,69 & 10,32 \\
\hline Garung & Endospermum malaccense & 1 & 2,63 & 0,33 & 7,69 & 10,32 \\
\hline Beringin & Diospyros laevigata bakh & 1 & 2,63 & 0,33 & 7,69 & 10,32 \\
\hline Purupuk & Lophophetalum spp & 1 & 2,63 & 0,33 & 7,69 & 10,32 \\
\hline & Total & 100 & 13 & 100 & & 200,00 \\
\hline
\end{tabular}

Sumber : Hasil Analisis, 2020 
Tabel 6 Hasil Analisis Vegetasi Tingkat Tanaman Bawah

\begin{tabular}{lccccccc}
\hline & Nama Jenis Vegetasi & \multirow{2}{*}{ K } & KR & F & FR & INP \\
\cline { 1 - 5 } \multicolumn{1}{c}{ Nama Lokal } & Nama Ilmiah & & & & & \\
\hline Pakis udang & Stenochlaena palustris & 0,1 & 58,5 & 0,3 & 50,0 & 108,5 \\
Pakis Sayur & Nephrolepis bisserata & 0,1 & 41,5 & 0,3 & 50,0 & 91,5 \\
\hline Jumlah & & $\mathbf{0 , 1}$ & $\mathbf{1 0 0 , 0}$ & $\mathbf{0 , 7}$ & $\mathbf{1 0 0 , 0}$ & $\mathbf{2 0 0 , 0}$ \\
\hline
\end{tabular}

Sumber : Hasil Analisis, 2020

Keterangan :

$\begin{array}{ll}\mathrm{K} & =\text { Kerapatan } \\ \mathrm{DR} & =\text { Dominasi Relatif } \\ \mathrm{KR} & =\text { Kerapatan Relatif } \\ \mathrm{FR} & =\text { Frekuensi Relatif }\end{array}$

Tabel 7 Indeks Keanekaragaman Jenis $\left(\mathrm{H}^{\prime}\right)$.

\begin{tabular}{ccc} 
No & Jenis Lahan & $\begin{array}{c}\text { Indeks Keanekaragaman } \\
\text { Jenis }\left(\mathbf{H}^{\prime}\right)\end{array}$ \\
\hline 1 & Jahe & 0 \\
2 & Karet & 0 \\
3 & Sawit & 0 \\
4 & Sekunder & 2,001 \\
\hline
\end{tabular}

Sumber : Hasil Analisis, 2020

Dari besarnya indeks nilai kepentingan (INP) dapat dilihat peranan spesies dalam masyarakat, di antaranya spesies dengan nilai INP tertinggi merupakan jenis yang dominan. Hal ini menunjukkan bahwa tipe ini lebih mudah beradaptasi dengan lingkungan dibandingkan tipe lainnya. Suatu jenis dikatakan dominan apabila jenis yang ditemukan dalam kisaran yang bersangkutan dalam jumlah yang besar, tersebar merata di seluruh zona dan memiliki jarak yang sangat jauh, sehingga penentuan jenis yang berlaku berdasarkan indeks yang dapat ditentukan berupa kombinasi dari tiga nilai, yaitu nilai kerapatan, nilai frekuensi dan nilai dominansi adalah sangat tepat (Yuningsih dkk, 2018).

Pada lahan sekunder yang pernah mengalami kebakaran pada tahun 2017 dan telah suksesi, vegetasi tingkat pohon yang mendominasi dan merupakan tanaman pioneer pada kelas penutupan lahan sekunder adalah Temasam (Syzgium cerina) sebesar $85,12 \%$. Sedangkan untuk tingkat pancang tanaman yang mendominasi dan merupakan tumbuhan pioneer adalah Mahang (Macaranga motleyana) dengan nilai INP sebesar 77,22\% yang merupakan pohon-pohon yang tertinggal karena gangguan, atau pohon-pohon di hutan dalam tahap regenerasi. Tanaman pionir memiliki karakteristik benih yang relatif kecil dan jumlah benih yang banyak serta penyebaran benih yang relatif jauh sehingga sering menetap di daerah terdegradasi. (Davies \& Semui , 2006).

Selain itu pada lahan yang telah terbakar umumnya juga didominansi tumbuhan alami gambut yaitu seperti pada tingkat semai Cengkodok (Melastoma malabathricum) dengan INP sebesar 91,50\% akan tumbuh satu tingkat di atas tanaman bawah yaitu pakis udang (Stenochlaena palustris) memiliki nilai INP 108,5\% yang menunjukkan bahwa lahan gambut yang terdegradasi berada pada tahap awal regenerasi alami (Eijk dkk, 2009)

Nilai indeks biodiversitas lahan jahe, karet dan kelapa sawit adalah \pm 0 (nol) yang berarti tidak terdapat biodiversitas vegetasi di daerah sampel jahe, karet dan sawit. Satu-satunya tipe yang teridentifikasi adalah tipe vegetasi komersial dengan nilai ekonomi dan nilai jual yang tinggi. Lahan jahe, karet dan sawit dapat dikategorikan biodiversitas rendah, dengan penyebaran jumlah individu tiap spesies rendah dan kestabilan komunitas rendah. Lahan Sekunder memiliki nilai indeks biodiversitas sebesar 2,001, nilai indeks keanekaragaman di lokasi ini merupakan nilai indeks keanekaragaman tertinggi di bandingkan dengan lokasi penelitian yang lainnya. Hal ini berarti tipe lahan sekunder termasuk dalam kategori keanekaragaman hayati sedang, jumlah individu tiap spesies tersebar sedang, dan stabilitas komunitas sedang.

\subsection{Perubahan Tutupan Lahan}

Pertambahan penduduk disertai dengan bertambahnya kebutuhan yang harus dipenuhi. Pemenuhan kebutuhan sandang, pangan dan papan telah meningkatkan kebutuhan akan lahan, yang menyebabkan terjadinya konversi lahan gambut menjadi lahan produktif untuk memenuhi kebutuhan sehari-hari. Fenomena ini dapat dikaitkan dengan berkurangnya hutan di lahan gambut dan terus meningkatnya permintaan produk pertanian (Miettinen dkk, 2012). Lahan gambut merupakan 
ekosistem yang unik dengan nilai ekonomi, nilai ekologi dan fungsi lingkungan (Ulya dkk, 2015).

\subsection{Dinamika Perubahan Tutupan Lahan}

Pada Tahun 2010 tutupan lahan Desa Teluk Empening didominasi lahan perkebunan, hutan sekunder, semak belukar dan tedapat areal permukiman. Namun, seiring berjalannya waktu dan meningkatnya kebutuhan terhadap lahan, terjadi perubahan tutupan lahan gambut pada Desa Teluk Empening. Pada Tahun 2020 seiring dengan meningkatnya kebutuhan lahan dan meningkatnya permintaan produk pertanian, area semak belukar gambut telah dikonversi menjadi areal persawahan.

\subsection{Dampak Sosial dan Ekonomi Konversi Lahan Gambut}

Konversi lahan gambut semakin meningkat dari tahun ke tahun dan mempengaruhi sosial ekonomi masyarakat dengan fungsi sosial penyerapan tenaga kerja serta fungsi ekonomi keuntungan dan pendapatan dari hasil produksi konversi lahan menjadi usahatani.

Masyarakat lokal di lahan gambut memilih sistem pertanian campuran dengan menanam berbagai jenis komoditas mulai dari tanaman semusim hingga tanaman tahunan. Sistem pertanian petani lokal ini merupakan upaya penyesuaian terhadap alam dengan cara menghindar (escape mechanism) sebagai kebalikan dari upaya menantang terhadap kondisi alam yang tidak menentu. Sistem mata pencaharian rangkap di atas juga dimaksudkan untuk mempertahankan keberlanjutan dalam pemenuhan kebutuhan di daerah yang kondisinya tidak menentu dan menghindari risiko kegagalan secara total (Umar, Noor, \& Noorginayuwati, 2016).

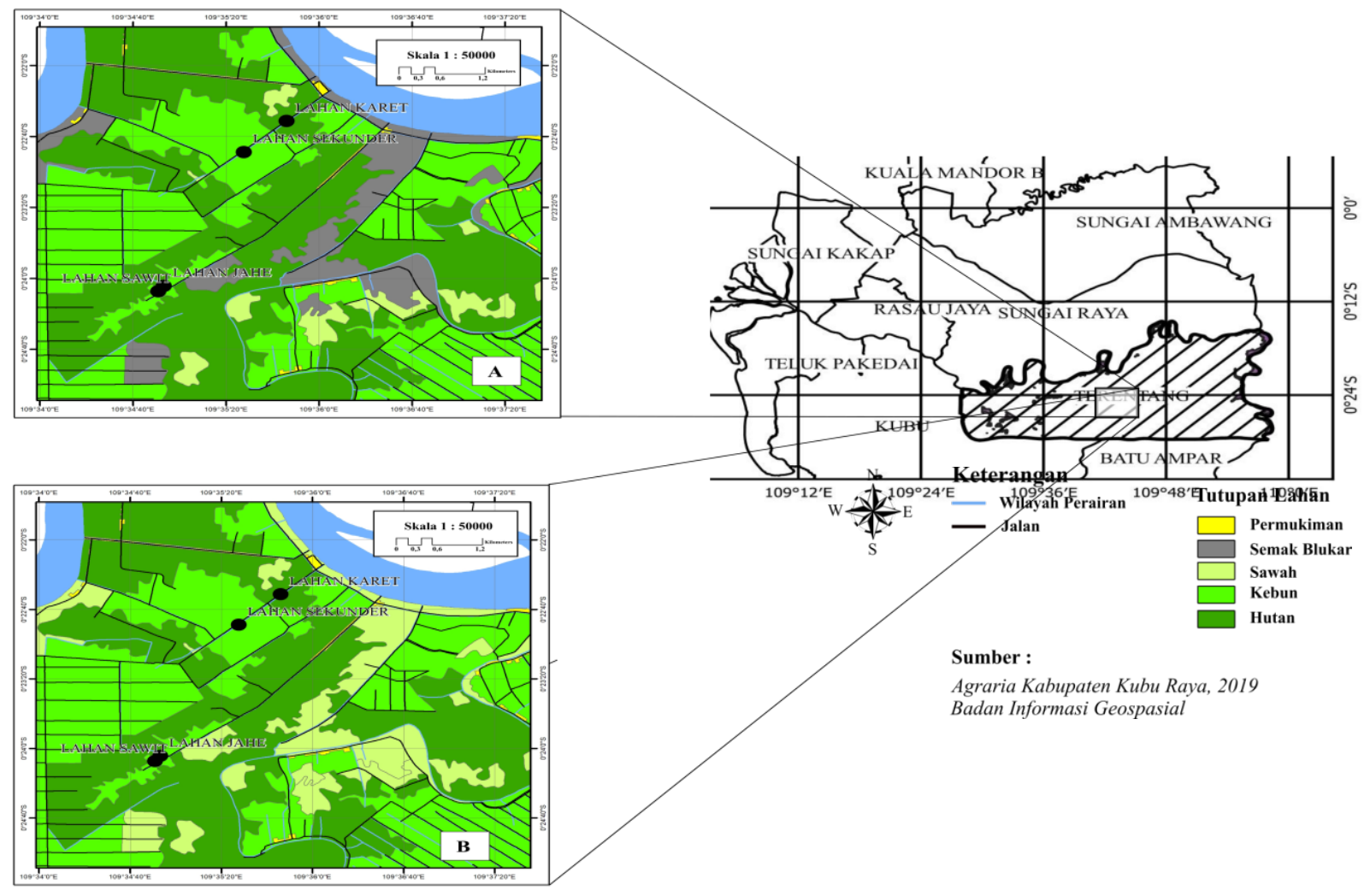

Gambar 2 Peta Tutupan Lahan Desa Teluk Empening : A. 2010 , B. 2020

Tabel 8 Keuntungan Usahatani

\begin{tabular}{ccccc}
\hline Jenis Komoditi & Total Biaya (Rp) & Total Penerimaan (Rp) & Total Keuntungan (Rp) & C/R rasio \\
\hline Jahe & Rp4.550.000 & Rp37.500.000 & Rp32.950.000 & 8 \\
Sawit & $\mathrm{Rp} 25.345 .000$ & $\mathrm{Rp} 74.880 .000$ & $\mathrm{Rp} 49.535 .000$ & 3 \\
Karet & $\mathrm{Rp} 16.000 .000$ & $\mathrm{Rp} 100.320 .000$ & $\mathrm{Rp} 84.320 .000$ & 6 \\
\hline
\end{tabular}




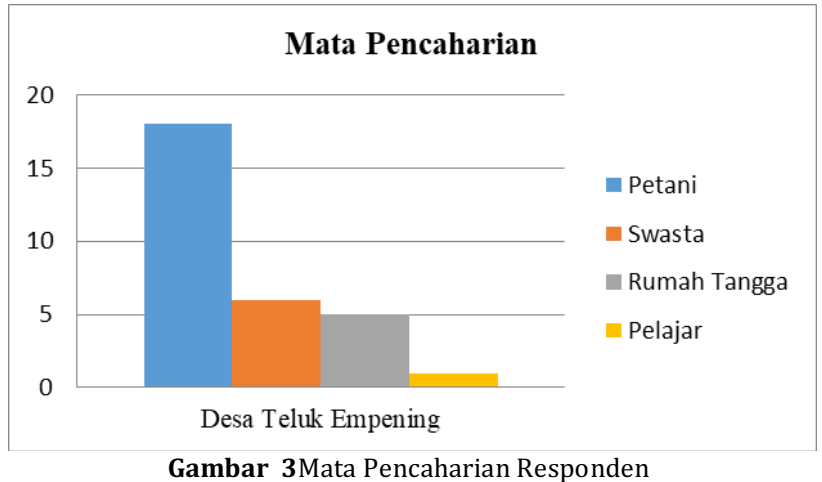

Mata pencaharian sebagai petani menunjukkan dampak fungsi sosial lahan gambut dalam penyerapan tenaga kerja masih sangat mungkin ditingkatkan, antara lain melalui pemanfaatan inovasi dan teknologi (inotek) pertanian mulai dari budidaya usahatani, panen, dan pengolahan hasil pertanian yang berdampak terhadap peningkatan intensitas tanam, produktivitas dan nilai tambah bagi petani (Irawan \& Maftuah, 2014).

Metode yang digunakan untuk mengetahui keuntungan usahatani adalah Revenue/ Cost Ratio yaitu merupakan perbandingan antara total penerimaan dengan total biaya dengan rumusan sebagai berikut:

$$
\mathrm{R} / \mathrm{C} \text { Ratio }=\frac{\text { Penerimaan }}{\text { Biaya }}
$$

Dari rumus diatas dapat diketahui kriteria dari $\mathrm{R} / \mathrm{C}$ Ratio sebagai berikut :

1. Apabila R/C Ratio > 1 maka usahatani dikatakan menguntungkan.

2. Apabila $\mathrm{R} / \mathrm{C}$ Ratio $=1$ maka usaha tani mengalami impas

3. Apabila R/C Ratio < 1 maka usahatani dikatakan tidak menguntungkan (rugi)

Pada Tabel 8 dapat diketahui bahwa usahatani yang mengkonversi lahan gambut menguntungkan bagi petani secara ekonomi. Hasil total keuntungan yang dirata-ratakan untuk kebutuhan tiap bulan didapatkan nilai pendapatan penduduk tiap bulan adalah sekitar Rp4.633.472. Besarnya upah minimum provinsi (UMP) Kabupaten Kubu Raya tahun 2020 adalah Rp2.433.000. Apabila pendapatan masyarakat Desa Teluk Empening dibandingkan dengan UMP, maka pendapatan ratarata petani lokal lebih besar dari UMP. Hal ini menggambarkan bahwa pendapatan dari hasil konversi lahan gambut dapat memenuhi kebutuhan hidup layak (KHL) masyarakat.

\section{Kesimpulan}

Sifat lahan gambut sangat bervariasi baik sifat fisik, kimia maupun biologi serta kondisi lingkungannya. Lahan gambut diketahui sebagai sumber daya alam yang rapuh atau rentan dengan perubahan karakteristik yang tidak ramah lingkungan. Oleh karena itu perlu pengelolaan yang spesifik agar tidak terjadi perubahan karakteristik yang menyebabkan peranannya semakin menurun Perubahan sifat gambut menunjukkan adanya lahan gambut yang dapat dimanfaatkan untuk pengembangan pertanian dan perlu dijaga untuk menjaga kelestarian lingkungan. Hilangnya fungsi lingkungan lahan gambut terjadi karena adanya perubahan komposisi ekosistem gambut. Proses degradasi fungsi lingkungan lahan gambut diawali dengan proses penebangan vegetasi alami dan drainase. Tiga fungsi gambut yaitu penyimpanan karbon, penyimpanan air dan perlindungan biodiversitas vegetasi yang pada saat bersamaan mengalami penurunan.

Penurunan biodiversitas vegetasi satu diantaranya ditandai dengan rendahnya nilai indeks keanekaragaman jenis $\left(\mathrm{H}^{\prime}\right)$ vegetasi pada lahan gambut. Rendahnya keanekaragaman jenis vegetasi di lahan gambut ini disebabkan oleh alih fungsi lahan gambut menjadi lahan usahatani dengan jenis tanaman homogen yang nemiliki nilai ekonomis. Peran lahan gambut sebagai sumber pendapatan keluarga petani sangat penting karena semakin banyak masyarakat yang mengandalkan lahan sub-optimal seperti lahan gambut. Umumnya, petani menanam tanaman pangan dan tanaman hortikultura musiman dan tahunan.

Berdasarkan hasil analisis konversi lahan gambut menjadi lahan usahatani memberikan dampak yang menguntungkan bagi petani lokal sebagai mata pencaharian dan layak menjadi usaha karena menguntungkan secara ekonomi. Pemilihan jenis komoditas usahatani harus mempertimbangkan kelayakan teknis, ekologis, dan ekonomis dari komoditas tersebut. Masyarakat biasanya memilih tanaman yang mudah tumbuh di lahan gambut, sehingga kelapa sawit dan karet dijadikan komoditas untuk bercocok tanam. Jika banyak kelapa sawit dan karet ditanam di lahan gambut akan menyebabkan emisi gas rumah kaca dan gambut menjadi kering dan mudah terbaka sehingga berpotensi merusak lingkungan.

\section{DAFTAR PUSTAKA}

Andriesse, J. (1988). Natural And Management Of Tropical Peat Soil. Bulletin Fao Soil, 59.

Barchia, M. F. (2012). Gambut Agroekosistem Dan Transformasi Karbon. Yogyakarta: UGM Press.

Dariah, A., Maftuah, E., \& Maswar. (2014). Karakteristik Lahan Gambut. Panduan Pengelolaan Berkelanjutan Lahan Gambut Terdegradasi (Pp. 16-29). Bogor: Badan Penelitian Dan Pengembangan Pertanian.

Dariah, A., \& Maswar. (2016). Isu Lingkungan Gambut Tropika Indonesia. In F. Agus , M. Anda, A. Jamil, \& Masganti, Lahan Gambut Indonesia Pembentukan, Karakteristik, Dan Potensi Mendukung Ketahanan Pangan (Edisi Revisi) (Pp. 101-129). Jakarta: IAARD Press. 
Davies, S., \& Semui , H. (2006). Competitive dominance in a secondary successional rain-forest community in Borneo. Journal of Tropical Ecology, 53-64.

Dombois, D., \& Heinz , E. (1974). Aims And Methods of Vegetation Ecology. Canada: John Wiley \& Sons, Inc.

Eijk, P. V., Leenman, P., Wibisono, I. T., \& Giesen , W. (2009). Regeneration and reforestation of degraded peat swamp forest in Berbak NP, Jambi, Sumatra,Indonesia. Malayan Nature Journal. 61(3), 223-241.

Faoziah, N., Iskandar, Djajakirana, G., Darmawan, \& Sumawinata, B. (2019). On The Development Of Measurement Procedure of Particle. Iop Conference Series: Earth And Environmental Science (Pp. 1-4). Bandung: Iop Publishing.

Gnatowski, T., Szatyłowicz, J., Brandyk, T., \& Kechavarzi, C. (2010). Hydraulic Properties Of Fen Peat Soils In Poland. Geoderma Volume 154, Issues 3-4, 188-195.

Irawan, \& Maftuah, E. (2014). Model Usahatani Pada Lahan Gambut. In N. Nurida, \& A. Wihardjaka , Panduan Pengelolaan Berkelanjutan Lahan Gambut Terdegradasi (Pp. 47-62). Bogor: Badan Penelitian Dan Pengembangan Pertanian, Kementeian Pertanian.(Pp. 131-162). Jakarta: Iaard Press.

Irma, W., Gunawan, T., \& Suratman. (2018). Pengaruh Konversi Lahan Gambut Terhadap Ketahanan Lingkungan. Jurnal Ketahanan Nasional, 170-191.

Lewis, C., Albertson, J., Xu, X., \& Kiely, G. (2011). Spatial Variability Of Hydraulic Conductivity And Bulk Density Along A Blanket Peatland Hillslope. Hydrological Processes, 141-160.

Mardiana, S. (2006). Perubahan Sifat-Sifat Tanah Pada Kegiatan Konversi Hutan Alam Rawa Gambut Menjadi Perkebunan Kelapa Sawit. Skripsi. Fakultas Kehutanan Ipb.

Masganti, Anwar, K., \& Susanti, M. A. (2017). Potensi Dan Pemanfaatan Lahan Gambut Dangkal Untuk Pertanian. Jurnal Sumber Daya Lahan, 43-52.

Melling, L., Goh, K. J., Chaddy, A., \& Hatano , R. (2016). Soil Co 2 Fluxes From Different Ages Of Oil Palm In Tropical Peatland Of Sarawak, Malaysia . Soil Carbon, 447-455.

Melling, L., Katimon, A., Joo , G., Uyo, L., Sayok, A., \& Hatano, R. (2007). Hydraulic Conductivity And Moisture Characteristics Of Tropical Peatland - Preliminary Investigation . Proceedings Of Soils Science Conferenceof Malaysia. Sarawak.

Munir, J., \& Herman, W. (2019). Fenomena Berbagai Sifat Fisika Dan Kimia Tanah Mendukungketahanan Tanaman Pangan Di Sumatera Barat. Ziraa'ah, Volume 44 Nomor $2,147-154$.

Najiyati, S., Muslihat, L., \& Suryadiputra, I. N. (2005). Pengelolaan Lahan Gambut untuk Pertanian Berkelanjutan. Bogor: Wetlands International Indonesia Programme.

Noor, M., Alwi, M., Mukhlis , Nursyamsi, D., \& Thamrin, M. (2013). Lahan Gambut : Pemanfaatan Dan Pengembangannya Untuk Pertanian. Kanisius. . Yogyakarta: 63-88.

Page, S., Hosciło, A., Wosten, H., Jauhiainen, J., Silvius, M., Rieley, J., Et Al. (2009). Restoration Ecology Of Lowland Tropical Peatlands In Southeast Asia: Current Knowledge And Future Research Directions. Ecosystems, 888-905.

Perdana, S., \& Wawan. (2015). Pengaruh Pemadatan Tanah Gambut Terhadap Sifat Fisik Pada Dua Lokasi Yang Berbeda. Jom Faperta Vol. 2 No. 2, 1-12.
Prabandini, G. (2016). Pengukuran Konduktivitas Hidrolik Gambut. Geophysics And Meteorology, 1-50.

Pranoto, D. Y., Hardiansyah, G., Diba, F., Fahrizah, Hendarto, Arief, F. B., Et Al. (2016). Penilaian Rencana Perlindungan Dan Pengelolaan Ekosistem. Seminar Nasional Penerapan Ilmu Pengetahuan Dan Teknologi (Pipt) (Pp. 1-13). Pontianak: Universitas Tanjungpura.

Ritzema, H., Limin, S., Kusin, K., \& Jauhiainen, J. (2014). Canal Blocking Strategies For Hydrological Restoration of Degraded Tropical Peatlands In Central Kalimantan, Indonesia. Catena, 11-20.

Rustam, Umar, H., \& Yusran. (2016). Sifat Fisika Tanah Pada Berbagai Tipe Penggunaan Lahan Di Sekitar Taman Nasional Lore Lindu (Studi Kasus Desa Toro Kecamatan Kulawi Kabupaten Sigi Sulawesi Tengah). Warta Rimba Volume 4, Nomor 1, 132-138.

Saribun, D. (2007). Pengaruh Jenis Penggunaan Lahan Dan Kelas Kemiringan Lereng Terhadap Bobot Isi, Porositas Total, Dan Kadar Air Tanah Pada Sub-Das Cikapundung Hulu. Skripsi. Jurusan Ilmu Tanah. Fakultas Pertanian.Universitas Padjajaran.

Sufardi, Basri, H., Ali, S., \& Khairullah. (2016). Perubahan Sifat Fisika Tanah Akibat Konversi Lahan Di Ekosistem Hutan Rawa Gambut Tripa Provinsi Aceh (Indonesia). Seminar Nasional Lingkungan Hidup Dan Mitigasi Bencana Di 28 Mai (Pp. 1-9). Pekanbaru: Universitas Syiah Kuala.

Supriharyono. ( 2009). Konservasi Ekosistem Sumberdaya Hayati Di Wilayah Pesisir Dan Laut Tropis. Yogyakarta: Pustaka Pelajar.

Surya, J. A., Nuraini , Y., \& Widianto, W. (2017). Kajian Porositas Tanah Pada Pemberian Beberapa Jenis Bahan Organik Di Perkebunan Kopi Robusta. Jurnal Tanah Dan Sumber Daya Lahan Volume 4 No 1, 463-471.

Susandi, Oksana, \& Arminuddin, A. T. (2015). Analisis Sifat Fisika Tanah Gambut Pada Hutan Gambut Di Kecamatan Tambang Kabupaten Kampar Provinsi Riau. Jurnal Agroteknologi, Vol. 5 No. 2, 23-28.

Suswati, D. B., Hendro, D., Shiddieq, \& Indradewa, D. (2011). Identifikasi Sifat Fisik Lahan Gambut Rasau Jaya Iii Kabupaten Kubu Raya Untuk Pengembangan Jagung. Jurnal Tek. Perkebunan \& Psdl, 31-40.

Turetsky, M. R., Benscoter, B., Page, S., Rein, G., \& van der Werf, G. R. (2015). Global vulnerability of peatlands to fire and carbon loss. Nature Geoscience, 8 .

Ulya, N., Warsito, S., \& Andayani, W. (2015). Nilai Ekonomi Karbon Hutan Rawa Gambut Merang Kepayang, Propinsi Sumatera Selatan. Jurnal Manusia Dan Lingkungan, Vol. 22, No.1, 52-58.

Umar, S., Noor, M., \& Noorginayuwati. (2016). Kearifan Lokal Untuk Peningkatan Dan Keberlanjutan Produksi Pertanian Di Lahan Gambut. In F. Agus , M. Anda, A. Jamil, \& Masganti, Lahan Gambut Indonesia Pembentukan, Karakteristik, Dan Potensi Mendukung Ketahanan Pangan (Pp. 163-188). Jakarta: Iaard Press.

Veloo, R., Ranst, E. v., \& Selliah, P. (2015). Peat Characteristics and its Impact on Oil Palm Yield. Journal of Life Sciences, $33-40$.

Wahdah, R. (2018 ). Hubungan Penurunan Volume Air Dengan Pemampatan Gambut Pada Tingkat Kematangan Yang Berbeda Di Kawasan Gambut Berengbengkel Kalimantan Tengah. Jukung Jurnal Teknik Lingkungan, 4 (2), 65 - 71.

Wasis , B., Kusmana, C., Suhendang, E., \& Sudarsono. (2005). Analisa Jenis Tanah Pada Hutan Tanaman Akasia 
(Acacia Mangium Willd) Di Blok Subanjeriji. Bagian Dari Disertasi Basuki Wasis (Pp. 1-11). Bogor: IPB.

Yule, C. M. (2010). Loss of biodiversity and

ecosystem functioning functioning in Indo-Malayan peat swamp forests. Biodiversity and Conservation, 393-409.

Yuliani, N. (2014). Teknologi Pemanfaatan Lahan Gambut Untuk Pertanian. Inovasi Teknologi Pertanian Spesifik Lokasi (Pp. 361-373). Banjarbaru 2014: Balai Pengkajian Teknologi Pertanian (Bptp) Kalimantan Selatan.
Yulnafatmawita , Luki , U., \& Yana, A. (2007). Kajian Sifat Fisika Tanah Beberapa Penggunaan Lahan Di Bukit Gajabuih Kawasan Hutan Hujan Tropik Gunung Gadut Padang. Jurnal Solum Vol. Iv No.2, 49-62.

Yuningsih, L., Bastony, Yulianty, T., \& Harbi, J. (2018). Analisis Vegetasi Pada Lahan Hutan Gambut Bekas Terbakar di Kabupaten Ogan Komering Ilir (OKI), Provinsi Sumatera Selatan, Indonesia. SYLVA, 58-67. 